\title{
Changes in Peripheral Levels of Immunoreactive Inhibin and Gonadotropins in Cattle Induced to Superovulate by Porcine Follicle-Stimulating Hormone
}

\author{
Hiroyuki Kaneko*, Takayoshi Terada*, Gen Watanabe,* Kazuyoshi Taya**, and Shuji Sasamoto** \\ ${ }^{*}$ Department of Animal Production, Kyushu National Agricultural Experiment Station, Nishigoshi, Kumamoto 861-11 and ${ }^{* *}$ Laboratory \\ of Veterinary Physiology, Tokyo University of Agriculture and Technology, Fuchu, Tokyo 183, Japan
}

(Accepted for publication December 6, 1989)

\begin{abstract}
Summary. Concentrations of inhibin in peripheral blood were determined in cattle treated with porcine follicle-stimulating hormone (FSH). Changes in plasma concentrations of FSH, luteinizing hormone ( $\mathrm{LH})$, estradiol and progesterone were also examined. These results were compared with hormonal profiles in the intact estrous cycle prior to FSH treatment of the same cows. Plasma levels of estradiol before ovulation and of progesterone after ovulation during the period of treatment with porcine FSH were much higher than those in the intact cycle. Concentrations of plasma inhibin rose promptly after injections of porcine FSH and maintained high levels for a longer period than estradiol after the LH surge. Changes in plasma concentrations of inhibin were not correlated to those of progesterone in superovulating cattle. In the superovulating animals, peaks of the preovulatory FSH surge were suppressed to $70.4 \%$ of the intact cycle, though $\mathrm{LH}$ peaks were not significantly suppressed. These results indicate that high levels of inhibin after treatment with porcine FSH may be involved in a partial suppression of the preovulatory surge of FSH in superovulating cattle. These findings also suggest that unovulated follicles maintain the ability to secrete inhibin and that the corpus luteum in superovulating cattle is not the active source of inhibin secretion.
\end{abstract}

KEY WORDS: PERIPHERAL INHIBIN, ESTRADIOL, GONADOTROPINS, SUPEROVULATING CATTLE.

Jpn J Anim Reprod 36, 77-82, 1990

Ovarian inhibin is one of the important factors which regulate FSH secretion in female animals and suppressed FSH biosynthesis in gonadotrophs (de Jong, 1988).

In cattle, inhibin is thought to be involved in the divergencies between FSH and LH secretion in the estrous cycle. For example, FSH concentrations during the follicular phase did not change whereas LH levels increased 2 or 3 fold (Ireland and Roche, 1982; Padmanabahn et al, 1984). Further, a small elevation of FSH was observed after the preovulatory gonadotropin surges though concentrations of LH decreased to low levels (Dobson, 1978; Walters and Schallenberger, 1984; Quirk and Fortune, 1986). Inhibin is probably involved in regulation of folliculogenesis by means of the negative feedback effects on FSH secretion, as suggested by Quirk and Fortune (1986).

There were several reports dealing with hormonal profiles in superovulating cattle (Saumande, 1980;
Saumande and Lopetz-Sebastian, 1982; Jensen et al., 1982; Lauria et al., 1982; Donaldson, 1985), though patterns of FSH and, in particular, inhibin were not examined.

In this study, we have investigated changes in peripheral levels of inhibin in cattle induced to superovulate by treatment with porcine FSH. Effects of elevation of inhibin levels on preovulatory FSH and LH secretion were also examined in relation to hormonal profiles during the intact estrous cycle.

\section{Materials and Methods}

\section{Reagents}

Porcine FSH preparation (pFSH; Denka Seiyaku, Co., Kawasaki, Japan) and prostaglandin $F_{2 \alpha}$ (PG; Daiichi Seiyaku Co., Tokyo, Japan) were used to induce superovulation. The weight of 40 Armour Units (A. U.) of porcine $\mathrm{FSH}$ preparation was $31.8 \mathrm{mg}$. 
Treatments and blood sampling

Four Japanese brown cattle, clinically normal with regular estrous cycles were used. Animals were given s.c. twice daily injections of pFSH (10:00 and 16:00) for 4 successive days starting 10 days after estrus ( 6 and 5 A.U. on the first day, 5 and 4 A.U. on the second day, 4 and 3 A.U. on the third day and 3 and 2 A.U. on the fourth day). Fifteen $\mathrm{mg}$ PG was administered i.m. two times at 48 and $56 \mathrm{hr}$ after the first pFSH injection. Estrous behavior (standing estrus) was checked every 4 hr. Blood samples were obtained via venipuncture every day from one day before the beginning to the end of pFSH treatment. When animals came into estrus, blood sample were taken every $2 \mathrm{hr}$ for $16 \mathrm{hr}$ and afterwards, every $4 \mathrm{hr}$ until $72 \mathrm{hr}$ after the beginning of estrus. Daily blood sampling was further continued by 7 days after estrus. Patterns of hormonal changes after pFSH treatment were compared with those in the intact estrous cycles of the same animals just before pFSH treatment. Blood samples were collected every $24 \mathrm{hr}$ from 5 or 6 days before anticipated estrus. When estrous behavior was noted, blood samples were obtained from each cow with the same frequancy as mentioned previously in pFSH treated animals.

\section{Determination of ovarian responses}

Number of ovulations was determined by counting corpora lutea through rectal palpation performed 7 days after estrus.

\section{Hormone assays}

Concentrations of $\mathrm{LH}$ in plasma were measured by radioimmunoassay (Echternkamp et al., 1976) using anti-ovine LH serum (DJB-3-1211), USDA-bLH-I1 for radioiodination and USDA-bLH-B-5 as a standard. The sensitivity of the assay, based on a $95 \%$ confidence limit of the mean for 6 replicate tests for the zero standard, was $0.006 \mathrm{ng} / \mathrm{tube}$. The intra- and inter- assay coefficients of variation were $6.6 \%$ and $11.7 \%$ respectively.

Concentrations of FSH in plasma were measured by radioimmunoassay (Bolt and Rollins, 1983) using antibovine FSH $\beta$-subunit antiserum (USDA-5-0012), purified bovine FSH (USDA-FSH-BP3) for radioiodination and USDA-FSH-B 1 as a reference standard. The sensitivity of FSH assay was $0.48 \mathrm{ng} /$ tube. The intraand inter- assay coefficients of variation were $5.9 \%$ and $4.9 \%$ respectively. Cross reaction between $\mathrm{pFSH}$ and antiserum against $\beta$-subunit of bovine $\mathrm{FSH}$ was $6.3 \%$, and antiserum against ovine $\mathrm{LH}$ was $0.6 \%$, respectively, at $50 \%$ of the binding in each assay.

Concentrations of estradiol and progesterone were determined as described previously (Taya et al., 1985) using antisera to estradiol-17 $\beta$ (GDN 244; Korenman $e t$ al., 1974) and progesterone (Gunma OGP-1; Takahashi et al., 1985). In the assay of estradiol, samples were defatted twice with the solution of mixture of $2 \mathrm{ml}$ $\mathrm{n}$-hexan and $0.5 \mathrm{ml} 50 \%$ methanol $(\mathrm{v} / \mathrm{v})$. The sensitivity of the assay were $0.63 \mathrm{pg} /$ tube for estradiol and 1.25 $\mathrm{pg} / \mathrm{tube}$ for progesterone. The intra- and inter- assay coefficients of variation were $6.0 \%$ and $12.4 \%$ for estradiol and $6.1 \%$ and $18.5 \%$ for progesterone, respectively.

Concentrations of inhibin in peripheral plasma were measured by a homologous double-antibody radioimmunoassay as described previously (Hamada et al., 1989) using antisera to bovine $32 \mathrm{kDa}$ inhibin (TNDH1). Pooled bFF was used as a reference standard and values estimated by the present radioimmunoassay were expressed as $\mathrm{nl} \mathrm{bFF} / \mathrm{ml}$. One $\mathrm{nl}$ of this reference standard corresponds to $5.17 \mathrm{pg}$ of purified $32 \mathrm{kDa}$ bovine inhibin. The intra- and inter-assay coefficients of variation were 8.3 and $17.4 \%$, respectively.

\section{Statistics}

The time of the preovulatory $\mathrm{LH}$ peak of each estrous cycle was designated as $0 \mathrm{hr}$ on Day 0 and hormonal profiles in the intact estrus cycle and those after the treatment with pFSH were compared. Plasma concentrations of LH, FSH, inhibin, estradiol and progesterone were subjected to a split plot in time design with repeated measurements (Gill and Hafs, 1971). Comparisons between hormonal concentrations of the intact cycle and those of the corresponding time after pFSH treatment were made using paired t-test. A value of $p<0.05$ was considered to be significant.

\section{Results}

\section{Ovarian responses}

The number of ovulations (corpora lutea) determined by rectal palpation after pFSH treatment were 3 in cows Nos. 1 and 4, and 5 in cow No. 3 and 10 in cow No. 2.

Changes in concentrations of plasma FSH and LH (Fig. 1, A and $B$ )

In the intact cycle, basal levels of plasma FSH ranged from 10 to $20 \mathrm{ng} / \mathrm{ml}$. Concentrations of FSH were significantly higher during the period of treatment with pFSH than those in the intact cycle from 12 to $72 \mathrm{hr}$ before the $\mathrm{LH}$ peak. The basal concentrations of plasma $\mathrm{LH}$ were under $1.5 \mathrm{ng} / \mathrm{ml}$ both in the intact cycle and after pFSH treatment. 


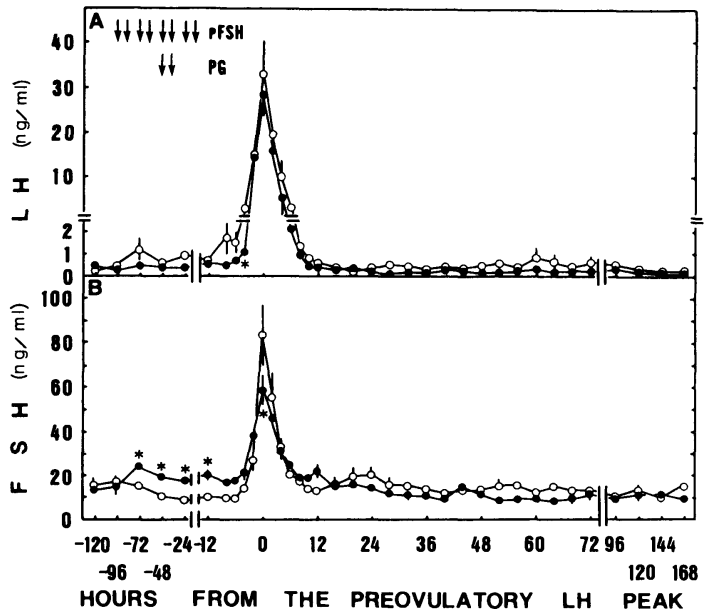

Fig. 1. Changes in plasma concentrations of $\mathrm{LH}$ (A) and FSH (B) relative to the preovulatory LH peak $(0 \mathrm{hr})$ in catthe after the administration of porcine FSH preparation (pFSH; a total doses of 32 A.U.) and prostaglandin $\mathrm{F}_{2^{\alpha}}$ (PG; a total doses of $30 \mathrm{mg}$ ) (O) or during the intact estrous cycle $(O)$. Results are expressed as mean \pm S.E.M. for four animals. Arrows indicate injections of pFSH and PG. ${ }^{*} \mathrm{p}<0.05$ compared with the value for the respective control (paired t-test).

The mean value of preovulatory $\mathrm{FSH}$ peaks was $84.9 \pm 13.0 \mathrm{ng} / \mathrm{ml}$ in the intact estrous cycle, whereas it was suppressed to $59.8 \pm 6.7 \mathrm{ng} / \mathrm{ml}$ after the treatment with $\mathrm{pFSH}$, being $70.3 \%$ of intact one $(\mathrm{p}<0.05)$. On the other hand, the preovulatory LH peaks were not significantly suppressed.

Changes in concentrations of plasma inhibin (Fig. 2, A)

Plasma concentrations of inhibin in the intact estrous cycles were $43.1 \mathrm{nl} / \mathrm{ml} 5$ days before estrus (Day 0) and increased to $76.5 \mathrm{nl} / \mathrm{ml}$ on estrus.

Plasma concentrations of inhibin significantly increased $48 \mathrm{hr}$ after the first pFSH injection (48 hr before the $\mathrm{LH}$ peak) when compared to the levels before the first pFSH injection (96 hr before the $\mathrm{LH}$ peak) and reached the maximum concentration of $947.5 \mathrm{nl} / \mathrm{ml}$ on estrus (Day 0). During the period of pFSH treatment, plasma concentrations of inhibin were higher than those in the control cycle from -48 to $48 \mathrm{hr}$ of the LH peak.

Changes in concentrations of plasma estradiol (Fig. 2, B)

Plasma concentrations of estradiol in the intact estrous cycle increased gradually during the follicular phase and reached peak values of $10 \mathrm{pg} / \mathrm{ml}$ on estrus, and then decreased less than $5 \mathrm{pg} / \mathrm{ml} 8 \mathrm{hr}$ after the LH

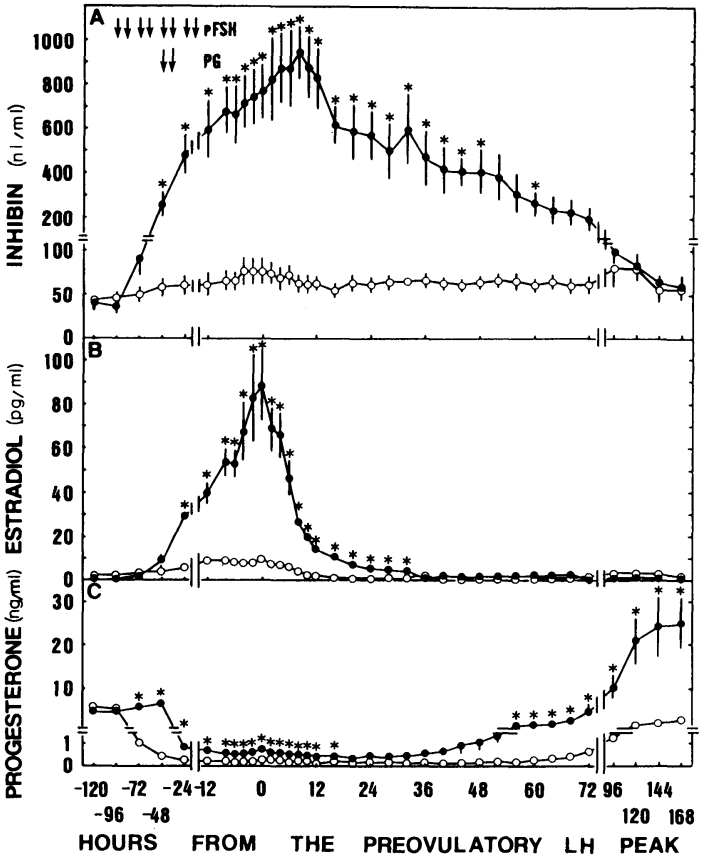

Fig. 2. Changes in plasma concentrations of inhibin (A), estradiol $(B)$ and progesterone $(\mathrm{C})$ relative to the preovulatory $\mathrm{LH}$ peak $(0 \mathrm{hr})$ in cattle after the administration of porcine FSH preparation (pFSH; a total doses of 32 A.U.) and prostaglandin $\mathrm{F}_{2 \alpha}(\mathrm{PG}$; a total doses of $30 \mathrm{mg}$ ) (O) or during the intact estrous cycle $(O)$. Results are expressed as mean \pm S.E.M. for four animals. Arrows indicate injections of pFSH and PG. ${ }^{*} \mathrm{p}<0.05$ compared with the value for the respective control (paired t-test).

peak. Concentrations of estradiol further declined thereafter (under $2 \mathrm{pg} / \mathrm{ml}$ ).

Concentrations of estradiol significantly increased 72 hr after the first pFSH injection ( $24 \mathrm{hr}$ before the $\mathrm{LH}$ peak) compared to pre-injection levels ( $96 \mathrm{hr}$ before the LH peak) and reached the maximum level of 88.8 $\mathrm{pg} / \mathrm{ml}$. During the period of treatment with $\mathrm{pFSH}$, plasma concentrations of estradiol significantly higher than those in the intact estrous cycle from -24 to $32 \mathrm{hr}$ of the LH peak.

Changes in concentrations of plasma progesterone (Fig. 2, C)

Plasma concentrations of progesterone in the intact estrous cycle decline from 6.2 to less than $1 \mathrm{ng} / \mathrm{ml} 48 \mathrm{hr}$ before the $\mathrm{LH}$ peak and remained under $0.3 \mathrm{ng} / \mathrm{ml}$ until $64 \mathrm{hr}$ after the LH peak. Thereafter, concentrations of progesterone increased and reached levels of $3.3 \mathrm{ng} / \mathrm{ml} 7$ days after estrus.

In animals treated with $\mathrm{pFSH}$, injections of PG induced luteolysis as seen by a fall in progesterone. 
Concentrations of progesterone after injections of PG were higher during the period of $\mathrm{pFSH}$ treatment than those in the intact estrous cycle from -24 to $16 \mathrm{hr}$ of the LH peak. Progesterone levels increased to high levels of $25 \mathrm{ng} / \mathrm{ml} 7$ days after estrus, significantly higher than intact levels.

\section{Discussion}

The present results indicate that peripheral immunoreactive inhibin increased progressively in cattle treated with pFSH for induction of superovulation in agreement with the previous reports in cows (Hasegawa et al., 1987) and ewes after the infusion of $\mathrm{FSH}$ (McNeilley et al., 1989).

Present results also indicate that plasma inhibin maintained high levels for a longer period than estradiol after the LH surge. The source of inhibin during these period is not clear. Large number of unovulated antral follicles of various sizes were detected after ovulation in FSH primed cows (Pierson and Ginther, 1984; Yadav et al., 1986). Inhibin- $\alpha$ and $-\beta$ A mRNAs were detected in bovine antral follicles (Rodgers $e t$ al., 1989) and granurosa cells from small or atretic follicles produced detectable amounts of inhibin (Henderson $e t$ al., 1984). On the other hand, after ovariectomy, half life of serum inhibin for the initial rapid decrease, represented most of the overall decay process, was determined to be $15 \mathrm{~min}$ in the female rats (Robertson et al., 1988). Therefore, it was suggested that unovulated follicles secreted inhibin and might be involved in the maintenance of elevated inhibin levels after the LH surge.

Any parallel changes between concentrations of plasma inhibin and progesterone were not observed in pFSH treated cows. These results were consistent with the previous study in which $\alpha$-and $\beta$ A-inhibin mRNAs were not detectable in fully developed bovine corpora lutea (Rodgers et al., 1989). Bovine corpus luteum did not produced detectable amounts of inhibin bioactivity (Henderson et al., 1981, 1983).

The present results clearly demonstrated that peaks of the preovulatory surge of FSH but not of LH were significantly suppressed in superovulating cattle, consistent with our preliminary examination (Kaneko et al., 1989). Tsukamoto et al. (1986) demonstrated that a marked increase in inhibin secretion completely blocked the periovulatory FSH surge, and further, Sasamoto et al. (1987) have demonstrated a quantitative relationship between inhibin secretion and suppression of the preovulatory $\mathrm{FSH}$ surge in superovulating rats. Tsonis et al. (1988) suggested that the supra physiologic- al levels of inhibin suppressed the occurrance of the FSH surge in ewes infused with ovine FSH. Therefore, a marked increase in inhibin secretion during the periovulatory period seemed to be responsible for the partial suppression of the FSH surge in the present experiments. Changes in endogenous $\mathrm{FSH}$ and $\mathrm{LH}$ during pFSH injections (from -72 to $-12 \mathrm{hr}$ from the $\mathrm{LH}$ peak) could not be determined due to the cross reaction between $\mathrm{pFSH}$ and antisera against bovine FSH- $\beta$ subunit and ovine $\mathrm{LH}$.

Previous reports indicated that a large amount of inhibin partially suppressed the LH surge in the intact (Rush et al., 1981) or in superovulating rats (Tsukamoto et al., 1986; Sasamoto et al., 1987) and superovulating ewes (Tsonis et al., 1987). Moreover, bovine or porcine follicular fluid and $32 \mathrm{kDa}$ porcine inhibin suppressed LH secretion stimulated by luteinizing hormone releasing hormone (LH-RH) in rat pituitary cell culture (de Jong et al., 1979, Fukuda et al., 1987). In the present study, however, a consistent and significant decrease in the preovulatory LH peak was not observed in superovulating cattle. The reasons why neither the partial suppression of the LH surge nor completely inhibition of the FSH surge occurred in superovulating cattle is not clear. Species differences may be exist in the potency of inhibin effects on gonadotropin secretion.

It seems unlikely that high levels of estradiol before gonadotropin surges were responsible for the suprression of the FSH surge. Estradiol induced an FSH surge in ovariectomized cattle (Kesner and Convey, 1982; Kesner et al., 1982) probably by increasing pituitary sensitivity to LH-RH due to an increase in the receptors for LH-RH in pituitary cells (Schoenemann et al., 1985, Clarke et al., 1988) and LH-RH pulse frequencies (Clarke and Cummins, 1985). In addition, progesterone also did not seem to contribute to the suppression of the preovulatory FSH surge, since progesterone levels after luteolysis induced by PG were under $1 \mathrm{ng} / \mathrm{ml}$

In summary, the present results indicate (1) that a marked increase in inhibin secretion partially suppressed the preovulatory surge of FSH, (2) that plasma inhibin rose earlier and high levels of plasma inhibin were maintained for a longer period than estradiol, and (3) that the corpus luteum may have no ability to secrete detectable amounts of inhibin, in cattle induced to superovulate with $\mathrm{pFSH}$.

\section{Acknowledgments}

We are grateful to Dr. D. J. Bolt of the USDA, Beltzville, MD, for providing RIA materials for bovine FSH and LH; Dr. G. D. Niswender, Department of 
Physiology and Biophysics, Colorado State University, CO, U.S.A. for providing antisera to estradiol-17 $\beta$ (GDN 244). We wish to express our gratitude to Drs K. Hasegawa and M. Igarashi, Department of Obstetrics and Gynecology, Gunma University, Maebashi, Japan for providing antisera to progesterone (Gunma OGP1). We also thanks to Teikoku Hormone MGF Co. Ltd., Tokyo for providing estradiol-17 $\beta$ and progesterone. This work was supported in part by a grant-in-aid (Bio Media Program) from the Ministry of Agriculture, Forestry and Fisheries. (BMP 89-II-1-2).

\section{References}

Bolt DJ, Rollins R (1983) Development and application of a radioimmunoassay for bovine follicle-stimulating hormone. J Anim Sci 56: 146-154.

Clarke IJ, Cummins JT (1985) Increased gonadotropinreleasing hormone pulse frequency associated with estrogen-induced luteinizing hormone surges in ovariectomized ewes. Endocrinology 116: 2376-2383.

Clarke IJ, Cummins JT, Crowder ME, Nett TM (1988) Pituitary receptors for gonadotropin-releasing hormone in relation to changes in pituitary and plasma gonadotropins in ovariectomized hypothalamo/pituitary disconnected ewes. II. A marked rise in receptor number during the acute feedback effects of estradiol. Boil Reprod 39: 349-354.

de Jong FH (1988) Inhibin. Physiological Reviews 68: 555-607.

de Jong FH, Smith SD, van der Molen HJ (1979) Bioassay of inhibin-like activity using pituitary cells in vitro. $J$ Endocr 80: 91-102.

Dobson H (1978) Plasma gonadotrophins and oestradiol during oestrous cycle in the cow. J Reprod Fert 52: 51-53.

Donaldson LE (1985) LH and FSH profiles at superovulation and embryo production in the cow. Theriogenology 23: $441-447$.

Echternkamp SE, Bolt DJ, Hawk HW (1976) Ovarian and pituitary hormones in blood of progesterone-treated ewes. J Anim Sci 42: 893-900.

Fukuda M, Miyamoto K, Hasegawa Y, Ibuki Y, Igarashi M (1987) Action mechanism of inhibin in vitroCycloheximide mimics inhibin action on pituitary cells. Mol Cell Endocr 51: 41-50.

Gill JL, Hafs HD (1971) Analysis of repeated measurements of animals. J. Anim Sci 33: 331-336.

Hamada T, Watanabe G, Kokuho T, Taya K, Sasamoto S, Hasegawa Y, Miyamoto K, Igarashi M (1989) Radioimmunoassay of inhibin in various mammals. $J$ Endocr 122: 697-704.

Hasegawa Y, Miyamoto K, Igarashi M, Yanaka T, Sakai K, Iwamura $S$ (1987) Changes in serum concentrations of inhibin during the estrous cycle of the rat, pig and cow.
In: Inhibin-Non-Steroidal Regulation of Follicle Stimulating Hormone Secretion (Burger HG, de Kretser DM, Findlay JK, Igarashi M eds.), Raven Press, New York. pp. 119-133.

Henderson KM, Franchimont P (1981) Regulation of inhibin production by bovine ovarian cells in vitro. $J$ Reprod Fert 63: 431-442.

Henderson KM, Franchimont P (1983) Inhibin production by bovine ovarian tissues in vitro and its regulation by androgens. J Reprod Fert 67: 291-298.

Henderson KM, Franchimont P, Charlet-Renard Ch, McNatty KP (1984) Effect of follicular atresia on inhibin production by bovine granulosa cells in vitro and inhibin concentrations in the follicular fluid. $J$ Reprod Fert 72: 1-8.

Ireland JJ, Roche JF (1982) Development of antral follicles in cattle after prostaglandin-induced luteolysis: changes in serum hormones, steroids in follicular fluid, and gonadotropin receptors. Endocrinology 111: 2077-2086.

Jensen AM, Greve T, Madej A, Edqvist LE (1982) Endocrine profiles and embryo quality in the PMSG-PGF $2 \alpha$ treated cow. Theriogenology 18: 33-44.

Kaneko H, Terada T, Goto K, Nakashima T, Ogata K, Kondoh M, Taya K, Sasamoto S (1989) Suppression of the preovulatory surge of FSH in superovulating cattle pretreated with porcine FSH. Jpn J Anim Reprod 35: 7-13.

Kesner JS, Convey EM (1982) Interaction of estradiol and luteinizing hormone releasing hormone on follicle stimulating hormone release in cattle. J Anim Sci 54: 817-821.

Kesner JS, Padmanabahn V, Convey EM (1982) Estradiol induces and progesterone inhibits the preovulatory surges of luteinizing hormone and follicle-stimulating hormone in heifers. Biol Reprod 26: 571-578.

Korenman SG, Stevens RH, Carpenter LA, Robb M, Niswender GD, Sherman BM (1974) Estradiol radioimmunoassay without chromatography: procedure, validation and normal values. J Clin Endocr Metab 38: 718-720.

Lauria A, Genazzani AR, Oliva O, Inaudi P, Cremonesi F, Monittola C, Aureli G (1982) Clinical and endocrinological investigations on superovulation induced in heifers by human menopausal gonadotrophin. J Reprod Fert 66: 219-225.

McNeilly AS, Swanston IA, Crow W, Tsonis CG, Baird DT (1989) Changes in the plasma concentrations of inhibin throughout the normal sheep oestrous cycle and after the infusion of FSH. $J$ Endocr 120: 295-305.

Padmanabahn V, Convey EM, Roche JF, Ireland JJ (1984) Changes in inhibin-like bioactivity in ovulatory and atretic follicles and utero-ovarian venous blood after prostaglandin-induced luteolysis in heifers. Endocrinology 115: 1332-1340. 
Pierson PA, Ginther OJ (1984) Ultrasonography of the bovine ovary. Theriogenology 21: 495-504.

Quirk SM, Fortune JE (1986) Plasma concentrations of gonadotrophins, preovulatory follicular development and luteal function associated with bovine follicular fluid-induced delay of oestrus in heifers. J Reprod Fert 76: 609-621.

Robertson DM, Hayward S, Ibry D, Jacobsen J, Clarke L, McLachlan RI, de Kretser DM (1988) Radioimmunoassay of rat serum inhibin: changes after PMSG stimulation and gonadoectomy. Mol Cell Endocr 58: 1-8.

Rodgers RJ, Stuchbery SJ, Findlay JK (1989) Inhibin mRNAs in ovine and bovine ovarian follicles and corpora lutea throughout the estrous cycle and gestation. Mol Cell Endocr 62: 95-101.

Rush ME, Ashiru OA, Lipner H, Williams AT, McRae C, Blake CA (1981) The actions of porcine follicular fluid and estradiol on preovulatory secretion of gonadotropic hormones in rats. Endocrinology 108: 2316-2323.

Sasamoto S, Taya K, Arakawa H, Kishi H (1987) Inhibin secretion and suppression of the FSH surge in superovulating animals. In: Inhibin-Non-Steroidal Regulation of Follicle Stimulating Hormone Secretion (Burger HG, de Kretser DM, Findlay JK, Igarashi M eds.), Raven Press, New York. pp. 219-232.

Saumande J (1980) Concentrations of luteinizing hormone, oetradiol-17 $\beta$ and progesterone in the plasma of heifers treated to induce superovulation. J Endocr 84 : 425-437.

Saumande J, Lopez-Sebastian A (1982) Changes in the plasma concentrations of free and conjugated oes- trogens in heifers after treatment to induce superovulation and the relationship with number of ovulation. J Reprod Fert 66: 411-416.

Schoenemann HM, Humphrey WD, Crowder ME, Nett TM, Reeves JJ (1985) Pituitary lutenizing hormonereleasing hormone receptors in ovariectomized cows after challenge with ovarian steroids. Biol Reprod 32: 574-583.

Takahashi Y, Hasegawa Y, Yazaki C, Igarashi M (1985) Direct radioimmunoassay of progesterone in rat serum. Endocrinol Japon 32: 661-672.

Taya K, Watanabe G, Sasamoto S (1985). Radioimmunoassay for progesterone, testosterone and estradiol-17 $\beta$ using ${ }^{125}$ I-iodohistamine radioligands. Jpn J Anim Reprod 31: 186-197 (in Japanese).

Tsonis CG, McNeilly AS, Baird DT (1988) Inhibin secretion by the sheep ovary during the luteal and follicular phase of the oestrous cycle and following stimulation with FSH. $J$ Endocr 117: 283-291.

Tsukamoto I, Taya K, Watanabe G, Sasamoto S (1986) Inhibin activity and secretion of gonadotropin during the period of follicular maturation. Life Sci 39: 119-125.

Walters DL, Schallenberger E (1984) Pulsatile secretion of gonadotrophins, ovarian steroids and ovarian oxytocin during the periovulatory phase of the oestruos cycle in the cow. J Reprod Fert 71: 503-512.

Yadav MC, Walton JS, Leslie, KE (1986) Timing of the onset and duration of ovulation in superovulated beef heifers. Theriogenology 26: 509-521.

\title{
FSH製阂投与による過排卵誘起牛における末梢血中インヒビン および性腺刺激ホルモンの変化
}

\author{
金子 浩之* ·寺田 隆慶 $*$ 渡辺 元 ${ }^{* *} \cdot$ 田谷 一善**. 笹本 修司 ${ }^{* *}$ \\ *農林水産省九州農業試験場 $\bar{\top} 861-11$ 熊本県菊池郡西合志町須屋2421 \\ **東京農工大学 $=183$ 府中市幸町 3-5 - 8
}

豚由来の FSH 製剤を投与したウシの末梢血中のイン ヒビン, FSH, LH, エストラジオールおよびプロジェ ステロン濃度を測定した。結果は, 同一牛の無処置の発 情周期中におけるホルモン濃度の变化と比較した。 FSH 投与群では，排卵前のエストラジオールおよび排 卵後のプロジェステロンの血漿中濃度は無処置時に比べ て著しく高値であった。血獎中インヒビン濃度は FSH 製剂投与後, 急激に上昇し, LH サージ後もエストラジ オールより長時間高值を維持した。血漿中インヒビンと
プロジェステロン濃度は, 過排卵誘起牛では関連した変 化を示さなかった。過排卵誘起群では排卵前の FSH サージのピーク値が無処置群の70.4\%に抑制されたが, LH サージは抑制されなかった。これらの結果より， $\mathrm{FSH}$ 製剤投与後の高濃度のインヒビンが排卵前の FSH サージを抑制するものと推察された。また,これらの知 見から，残存卵胞がインヒビン分泌活性を保持している こと, 並びに黄体は過排卵誘起牛ではインヒビンの主要 な分泌源ではないことが示唆された。 